\title{
Cytotoxic Effect of Laurocerasus officinalis Extract on Human Cancer Cell Lines
}

\author{
Selim DEMİR, İbrahim TURAN, Feyza DEMİR, Elif AYAZOĞLU DEMİR, Yüksel ALIYAZICIOĞLU
}

\begin{abstract}
Laurocerasus officinalis Roem. (Prunus laurocerasus L.), also locally known as "karayemis or taflan", is a popular black summer fruit belonging to the genus Prunus and the family Rosaceae. L. officinalis exhibits numerous biological activities, such as anti-inflammatory, antinociceptive, antioxidant, neuroprotective, and antidiabetic effects. The aim of this study was to determine the total phenolic content and cytotoxic effect of dimethyl sulfoxide extract of $L$. officinalis (DEL). The total phenolic content and cytotoxic effect of DEL were investigated using the Folin-Ciocalteu method and thiazolyl blue tetrazolium bromide (MTT) assay, respectively. Total phenolic content value
\end{abstract}

was $33.7 \pm 0.13 \mathrm{mg}$ gallic acid equivalent per g sample. DEL exhibited selective cytotoxic effects against four human cancer (lung, colon, liver, and cervix) cell lines. The most selective cytotoxic effect of the extract was observed in colon cancer cells $\left(\mathrm{IC}_{50}=265.2 \pm 8.1 \mu \mathrm{g} / \mathrm{mL}\right)$ compared to normal fibroblast cells. These data demonstrate that $L$. officinalis extract exhibits selective cytotoxicity towards some cancer cells. Further studies are now needed to clarify the molecules involved and their mechanisms.

Keywords: Antioxidant activity, Cherry laurel, Cytotoxic effect, Laurocerasus officinalis, Polyphenolic compounds
Selim Demir

Karadeniz Technical University, Faculty of Health Sciences, Department of Nutrition and Dietetics, 61080, Trabzon.

\section{İbrahim Turan}

Gumushane University, Faculty of Engineering and Natural Sciences, Department of Genetic and Bioengineering, 29100, Gümüshane.

Gumushane University, Medicinal Plants, Traditional Medicine Practice and Research Center, 29100, Gümüşhane.

Feyza Demir, Yüksel Aliyazıcıoğlu

Karadeniz Technical University, Faculty of Medicine, Department of Medical Biochemistry, 61080, Trabzon.

Elif Ayazoğlu Demir

Karadeniz Technical University, Faculty of Sciences, Department of Chemistry, 61080, Trabzon

Corresponding Author:

Selim Demir

e-mail:selim-demir@hotmail.com

Submitted / Gönderilme: 15.08 .2016 Accepted / Kabul: 03.10.2016
Revised / Düzeltme: 28.09.2016

\section{INTRODUCTION}

Laurocerasus officinalis Roem. (Prunus laurocerasus L.) belongs to the genus Prunus and the family Rosaceae. It is a popular dark blue or black fruit growing particularly in the Black Sea region of Turkey. The plant is also known as cherry laurel in the English-language literature, and is grown in some Balkan, Western Europe, Middle Eastern and Mediterranean countries. This fruit is very popular in Turkey as a foodstuff and is consumed not only in fresh form, but also in the forms of jam, marmalade or fruit juice (1-4). It is regarded as a good source of nutrients due to the content of monosaccharides, ascorbic acid, dietary fiber, various minerals, and phenolics, such as chlorogenic, benzoic, vanillic, and caffeic acid (5). This fruit is used to treat several diseases in Turkish traditional medicine, such as eczema, sore throat, asthma, coughs, stomach ache, and hemorrhoids $(1-4,6)$. Recent studies have reported anti-inflammatory, antinociceptive, antioxidant, anti-atherosclerotic, and antidiabetic activities of $L$. officinalis, and these beneficial activities have been attributed to the compounds listed above (1,4-7). 
Cancer is a major health problem and the second most important cause of death after cardiovascular diseases (8). According to the World Health Organization, cancer accounted for $13 \%$ of the total 58 million deaths worldwide in 2005 (9). Although chemotherapy is one effective means of treating several types of cancers, it also has a number of disadvantages, such as toxic effects on normal cells, ineffectiveness and gradual drug resistance occuring in cancer cells (10). In order to solve these problems, the scientific community has begun looking for efficient chemotherapeutics, and natural products are regarded as novel candidates for the development of new chemotherapeutics due their high anticancer activity and lower levels of toxicity in normal cells (11).

Several studies have investigated the cytotoxic effect of different species of the genus Prunus. Nabende et al. demonstrated that methanolic extract from the leaves of Prunus africana exhibits selective cytotoxic effects in mouse breast and colon cancer cells compared to monkey kidney (Vero) cells (12). Poongodi et al. reported that methanolic Prunus angustifolia leaf extract has a cytotoxic effect in human breast cancer cells (13). Peach polyphenolics isolated from Prunus persica have recently been reported to inhibit in vivo tumor growth by the inhibition of metalloproteinase (MMP) gene expression (14). However, to the best of our knowledge there have been no previous studies of the cytotoxic effect of L. officinalis. The purpose of this study was to determine the cytotoxic effect of dimethyl sulfoxide (DMSO) extract of $L$. officinalis (DEL) in human prostate (PC-3), breast (MCF-7), colon (WiDr), lung (A549), liver (HepG2), and cervix (HeLa) cancer cell lines and human normal foreskin fibroblast cells.

\section{MATERIALS AND METHODS}

\section{Plant Material}

The fruits of $L$. officinalis were collected from Yomra, Trabzon-Turkey in Summer 2015, and identified by Dr. Ibrahim Turan. These were air-dried at $25^{\circ} \mathrm{C}$ and powdered using a blender and milling into fine powder.

\section{Plant Extraction}

The fruit powder $(1 \mathrm{~g})$ was extracted with $20 \mathrm{~mL}$ DMSO in a mechanical shaker (Shell Lab, Cornelius, OR, USA) in the dark for $24 \mathrm{~h}$ at $45^{\circ} \mathrm{C}$. The suspension was subsequently removed by centrifuging at $3000 \mathrm{rpm}$ for $10 \mathrm{~min}$. Supernatants were filtered with Whatman No.1 filter paper and $0.2 \mu \mathrm{m}$ filters. Prepared $50 \mathrm{mg} / \mathrm{mL}$ stock extract was used for further experiments.

\section{Chemicals}

DMSO, sodium carbonate, Folin reagent, gallic acid, chlorogenic acid, cisplatin, trypan blue solution, thiazolyl blue tetrazolium bromide (MTT dye), and phosphate buffer saline (PBS) tablets were purchased from Sigma (St. Louis, MO, USA). Penicillin-streptomycin and trypsin were obtained from Biological Industries (Kibbutz Beit Haemek, Israel). Eagle's Minimum Essential Medium (EMEM) was obtained from Lonza (Verviers, Belgium). Fetal bovine serum (FBS) was purchased from Biochrom (Berlin, Germany).

\section{Drug Preparation and Treatment}

Cisplatin was dissolved in DMSO and used as a reference compound due to its frequent use in previous cytotoxicity studies $(11,15)$. Chlorogenic acid was dissolved in ethanol and used as a single phenolic since it is one of the major phenolics of $L$. officinalis $(16,17)$. Final solvent concentrations were no higher than $0.5 \%$ in culture media in any experiment. That concentration was not sufficient to affect cell morphology or viability.

\section{Determination of Total Phenolic Content}

The total phenolic content was established using the spectrophotometric method (18) adapted to microscale using gallic acid as a standard. Briefly, $12.5 \mu \mathrm{L}$ DEL was mixed with $62.5 \mu \mathrm{L}$ Folin reagent and $125 \mu \mathrm{L} 20 \%$ sodium carbonate. This was incubated at room temperature for 30 min, after that absorbance was measured at $760 \mathrm{~nm}$. The results were calculated using a standard gallic acid chart and were expressed as milligrams of gallic acid equivalent (GAE) per g sample. Experiments were performed in triplicate, and data are represented as mean $\pm S D$.

\section{Cell Culture}

Prostate adenocarcinoma (PC-3), hepatocellular carcinoma (HepG2), colon adenocarcinoma (WiDr), cervix adenocarcinoma (HeLa), breast adenocarcinoma (MCF-7), lung carcinoma (A549) human cancer and normal foreskin fibroblast cells were purchased from the America Type Culture Collection (Manassas, VA, USA). Cells were cultured in EMEM supplemented with $10 \% \mathrm{FBS}$, and $1 \%$ penicillinstreptomycin. Cultures were maintained at $37^{\circ} \mathrm{C}$ in $5 \% \mathrm{CO}_{2}$ and $95 \%$ air.

\section{Cytotoxicity Analysis}

The cytotoxic effects of DEL, chlorogenic acid, and cisplatin on cell proliferation were determined using MTT assay (19) with minor modifications. Briefly, $5 \times 10^{3}$ cells were seeded into a flat-bottomed 96-well cell culture plate and incubated for $24 \mathrm{~h}$. The cells were then treated with various 
concentrations of DEL $(0-500 \mu \mathrm{g} / \mathrm{mL})$, chlorogenic acid (0$500 \mu \mathrm{g} / \mathrm{mL})$ and cisplatin $(0-10 \mu \mathrm{g} / \mathrm{mL})$ for $72 \mathrm{~h}$. Next, 10 $\mu \mathrm{L}$ of MTT solution $(0.25 \mathrm{mg} / \mathrm{mL})$ was added into the wells and incubation continued at $37^{\circ} \mathrm{C}$ for $2 \mathrm{~h}$. The supernatants were then removed, and $200 \mu \mathrm{L}$ of DMSO was added into the wells for $2 \mathrm{~h}$. Optical density (OD) at $570 \mathrm{~nm}$ was determined using a microplate reader (Versamax, Molecular Devices, California, USA). The percentage of cell viability was calculated using the equation: $\mathrm{OD}$ of the treated group/OD of the control group $\times 100$ (11). Experiments were performed in triplicate, and data are represented as mean $\pm \mathrm{SD}$.

\section{RESULTS}

Total polyphenolic content was $33.7 \pm 0.13 \mathrm{mg}$ GAE per $\mathrm{g}$ sample. All cells were treated with various concentrations of DEL, chlorogenic acid and cisplatin, and their effects on cell growth were determined using MTT assay after $72 \mathrm{~h}$ (Figure 1). The $\mathrm{IC}_{50}$ values are shown in Table 1 . DEL exhibited moderate selective cytotoxicity against WiDr and A549 cells compared to fibroblast cells.
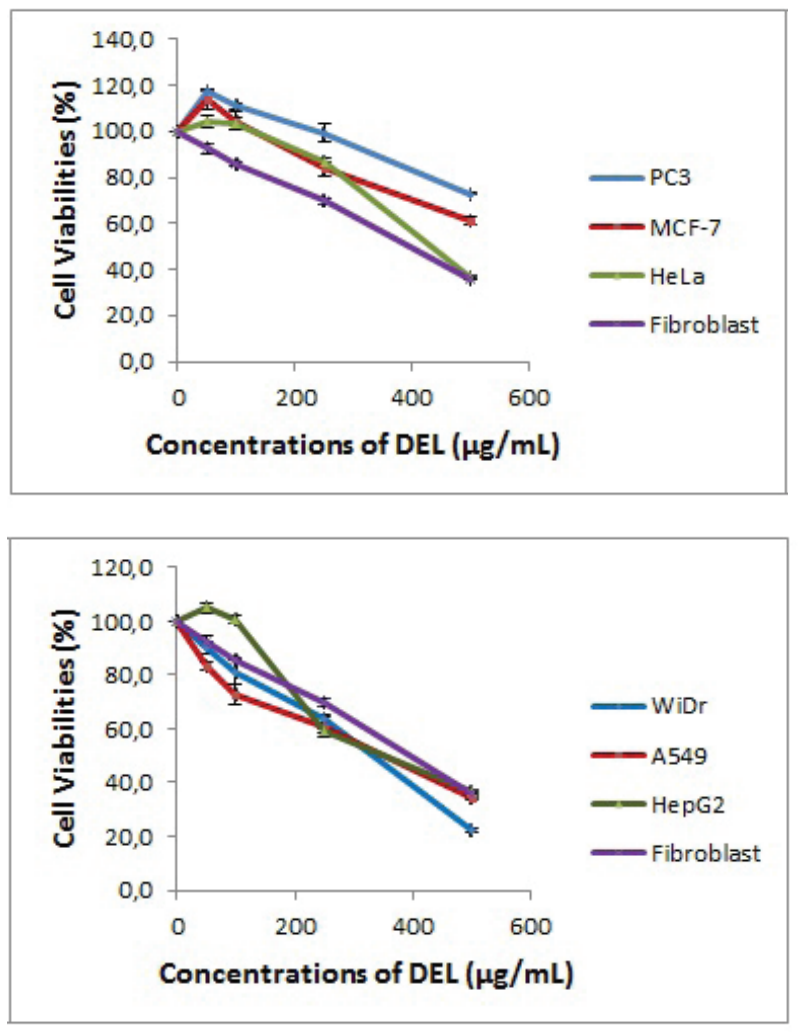

Figure 1. The anti-growth effect after the treatment with the DEL for $72 \mathrm{~h}$ against human cancer and normal fibroblast cells by the MTT assay $(n=3)$.
Table 1. Cytotoxic activities $\left(\mathrm{IC}_{50}, \mu \mathrm{g} / \mathrm{mL}\right)$ of DEL and other test compounds (mean $\pm \mathrm{SD}, \mathrm{n}=3$ ).

\begin{tabular}{llcc}
\hline & \multicolumn{3}{c}{ TEST COMPOUNDS } \\
\cline { 2 - 4 } & DEL & Chlorogenic acid & Cisplatin \\
PC-3 & $>500$ & $>500$ & $0.55 \pm 0.02$ \\
MCF-7 & $>500$ & $30.9 \pm 1.2$ & $0.39 \pm 0.02$ \\
WiDr & $265.2 \pm 8.1$ & $185.8 \pm 1.5$ & $1.28 \pm 0.01$ \\
A549 & $314.5 \pm 10.8$ & $456.6 \pm 3.8$ & $0.73 \pm 0.03$ \\
HepG2 & $357.1 \pm 4.8$ & $117.5 \pm 1.5$ & $2.47 \pm 0.21$ \\
HeLa & $396.1 \pm 5.4$ & $178.3 \pm 4.7$ & $0.62 \pm 0.02$ \\
Fibroblast & $359.1 \pm 5.5$ & $92.5 \pm 2.4$ & $4.79 \pm 0.14$ \\
\hline
\end{tabular}

\section{DISCUSSION}

This study investigated both the phenolic content of DEL and the cytotoxic effect of DEL on human prostate, breast, colon, lung, liver, and cervix cancer cells and human normal fibroblast cells. Total phenolic content is often used to determine the antioxidant properties of plant extracts since it constitutes an effective, rapid and inexpensive assay (20). A direct relationship has been observed between the total polyphenolic contents and antioxidant activity of many natural product extracts (21). We therefore elected to determine antioxidant capacity of DEL using the FolinCioceltau method. The total polyphenolic content of DEL in this study was $33.7 \pm 0.13 \mathrm{mg}$ GAE per g sample. The total polyphenolic content values of various extracts of $L$. officinalis fruits from different regions are reported range between 23.6 and $64.6 \mathrm{mg}$ GAE per g extract $(4,22)$. In that respect, our results are consistent with the literature. Small differences may have been due to the type of extraction method and solvent used, environmental factors, soil, geographic region, and the maturity levels of the fruits.

Cancer is one of the most important malignant diseases. The most commonly diagnosed cases involve the lungs (13\%), breast (11.9\%), and colon (9.7\%) (12). Chemotherapy is often used in treatment, but this can result in some side-effects, such as increased drug resistance in cancer cells and harmful effects in healthy cells over time. Natural products already 
play critical roles in cancer chemotherapy based on their ability to produce apoptosis and/or growth arrest in cancer cells without causing cytotoxic effects in healthy cells $(11,23)$. L. officinalis is one of the most important species of the genus Prunus, the fruits containing substantial levels of phenolics, flavonoids, and ascorbic acid $(5,16,17)$. Various experiments have evaluated in vitro antiproliferative characteristics of different Prunus species in recent years $(12,13)$. However, there are no previous studies of the cytotoxic effect of $L$. officinalis extract in the literature. In order to study new therapeutic approaches, cell lines are used to investigate novel compounds and their effects on tumor cells. If positive results are obtained from in vitro experiments, then in vivo studies are recommended (11). Effectiveness (high efficacy against multiple cancers) and the absence of deleterious effects on normal cells are two of the main properties desired in an effective chemotherapeutic agent (24). The current study was therefore performed on six different cancer cells and normal fibroblast cells under in vitro conditions. The findings show that DEL has no significant antiproliferative effect on PC-3 and MCF-7 cells up to concentrations of $500 \mu \mathrm{g} / \mathrm{mL}$. However, it exhibits selective cytotoxic effects, particularly on WiDr and A549 cells, compared to fibroblast cells. Lee et al. demonstrated that methanolic extract of Prunus serrulata exhibits a cytotoxic effect on human colon cancer (HT-29) cells. The highest inhibition in that study was observed at $38.8 \%$ at a concentration of $500 \mu \mathrm{g} / \mathrm{mL}$ of extract (23). Fujii et al. reported that Prunus domestica extract exhibits a selective cytotoxic effect on human colon cancer cells compared to normal colon cells via induction of apoptosis (25), while Adachi et al. reported that DMSO extract of Prunus mume Sieb. et Zucc has a cytotoxic effect on human stomach and promyelocytic leukemia cancer cells with no harmful effects on human blood cells (26). Studies have also investigated the antiproliferative activity of various compounds isolated from Prunus species. Jeong et al. reported that n-hexane fraction of methanolic extract of Prunus mume inhibits the growth of human larynx carcinoma (Hep-2) and ovary adenocarcinoma (SK-OV-3) cells in a concentration-dependent manner. Moreover, a new compound known as B-1 was purified from the $\mathrm{n}$-hexane fraction, and this exhibits a powerful cytotoxic effect on human kidney hypernephroma (SW-156), uterus adenocarcinoma (HEC-1-B), SK-OV-3, and Hep-2 cancer cells. The $\mathrm{IC}_{50}$ values of this compound range from 39 to 58 $\mu \mathrm{g} / \mathrm{mL}$ (27). Sunaga et al. reported that MK615, a compound isolated from Prunus mume fruits, exhibits a cytotoxic effect on human lung cancer cells via induction of autophagy and $G_{0} / G_{1}$ cell cycle arrest and the downregulation of interleukin-8 expression (28). Chlorogenic acid was used as a single polyphenolic compound in our study since it is one of more abundant polyphenols in L. officinalis $(16,17)$. Our findings show that the $\mathrm{IC}_{50}$ values of DEL were generally higher than those of chlorogenic acid (except for A549 cells). For this reason, the cytotoxic effect of DEL on four cancer cell lines may not derive only from chlorogenic acid, and this result may explain the synergistic effect of all fruit constituents.

Polyphenols are a major class of secondary herbal metabolites. The antioxidant effect of phenolic compounds is attributed to their ability to donate electrons to reactive oxygen species (ROS) chelating metal ions and stimulating antioxidant and detoxifying enzymes $(29,30)$. There are also several reports concerning their antioxidant, anticarcinogenic, antimutagenic, anti-atherosclerotic, antimicrobial, and antiinflammatory activities $(31,32)$. It has been suggested that the anticancer effect of phenolics may derive from their ability to modulate carcinogen metabolism, regulation of gene expression, induction of cell cycle arrest and apoptosis, and inhibition of signal transduction pathways (9). The presence of many phenolics (gallic, protocatechuic, $p$-hydroxybenzoic, chlorogenic, syringic, vanillic, caffeic, $p$-coumaric, and hydroxycinnamic acids, catechin, and rutin) has been shown in extracts of $L$. officinalis $(16,17)$, and there are many reports of antiproliferative activities of these phenolics in different cancer cells (33-35). We therefore think that the antiproliferative activity of DEL in cancer cells may derive from its phenolic content.

\section{CONCLUSIONS}

This study is the first comprehensive study to investigate the cytotoxic effect of $L$. officinalis extract on cancer cells in vitro conditions. From that perspective, this study opens up new pharmacological avenues. Further studies are now necessary to obtain a more detailed understanding of the exact interaction of the signaling pathways involved.

\section{Conflicts of interest statement}

None of the authors had any financial or personal relationships with other individuals or organizations that might inappropriately influence their work during the submission process. 
Laurocerasus officinalis Ekstraktının İnsan Kanser Hücre Serileri Üzerindeki Sitotoksik Etkisi

\section{ÖZ}

Laurocerasus officinalis Roem. (Prunus laurocerasus L.), yerel olarak karayemiş veya taflan olarak da bilinir, Prunus cinsi ve Rosaceae familyasına mensup, koyu renkli bir yaz meyvesidir. L. officinalis, anti-inflamatuvar, antinosiseptif, antioksidan, nöroprotektif ve antidiyabetik gibi çeşitli biyolojik aktiviteler göstermektedir. Bu çalıșmanın amacı, L. officinalis'in dimetil sülfoksitli ekstraktının antioksidan ve sitotoksik etkilerini belirlemektir. Ekstraktın toplam polifenol içeriği Folin-
Ciocalteu metodu, sitotoksik etkinliği ise MTT yöntemiyle belirlendi. Ekstraktın toplam polifenol içeriği $33.7 \pm 0.13 \mathrm{mg}$ gallik asit ekivalanı/g örnek olarak bulundu. Ekstrakt akciğer, kolon, karaciğer ve serviks kanser hücre serilerinde seçici bir sitotoksik etki gösterdi. Normal fibroblast hücreleri ile karşılaştırıldığında en etkili seçici sitotoksik etkinin kolon kanseri hücrelerinde olduğu belirlendi $\left(\mathrm{IC}_{50}=265.2 \pm 8.1 \mu \mathrm{g} / \mathrm{mL}\right.$ ). Sonuçlar L. officinalis ekstraktının bazı kanser hücre serilerinde seçici bir sitotoksik etki gösterebildiğini ortaya koymaktadır. Ekstrakttaki etken molekülleri ve bunların etki mekanizmalarını belirleyebilmek için daha ileri çalışmalara ihtiyaç vardır.

Anahtar kelimeler: Antioksidan aktivite, Karayemiş, Laurocerasus officinalis, Sitotoksik etki, Polifenolik bileşikler

\section{REFERENCES}

1. Erdemoglu N, Kupeli E, Yesilada E. Anti-inflammatory and antinociceptive activity assessment of plants used as remedy in Turkish folk medicine. J Ethnopharmacol 2003; 89: 123-9.

2. Kolayli S, Kucuk M, Duran C, Candan F, Dincer B. Chemical and antioxidant properties of Laurocerasus officinalis Roem. (Cherry laurel) fruit grown in the Black Sea region. J Agric Food Chem 2003; 51: 7489-94.

3. Liyana-Pathirana CM, Shahidi F, Alasalvar C. Antioxidant activity of cherry laurel fruit (Laurocerasus officinalis Roem.) and its concentrated juice. Food Chem 2006; 99: 121-8.

4. Celep E, Aydin A, Yesilada E. A comparative study on the in vitro antioxidant potentials of three edible fruits: Cornelian cherry, Japanese persimmon and cherry laurel. Food Chem Toxicol 2012; 50: 3329-35.

5. Karabegovic IT, Stojicevic SS, Velickovic DT, Nikolic NC, Lazic ML. Optimization of microwave-assisted extraction of cherry laurel fruit. Separ Sci Technol 2014; 49: 416-23.

6. Akbulut S, Bayramoglu MM. Reflections of socio-economic and demographic structure of urban and rural on the use of medicinal and aromatic plants: The sample of Trabzon province. Ethno Med 2014; 8: 89-100.

7. Senayli A, Sahin A, Senayli Y, Elmastas M. Evaluation the anti-diabetic activity of cherry laurel (Laurocerasus officinalis). Open Conf Proc J 2012; 3: 8-12.

8. Reddy L, Odhav B, Bhoola KD. Natural products for cancer prevention: a global perspective. Pharmacol Ther 2003; 99 : $1-13$.

9. Huang WY, Cai YZ. Natural phenolic compounds from medicinal herbs and dietary plants: potential use for cancer prevention. Nutr Cancer 2010; 62: 1-20.

10. Gottesman MM. Mechanism of cancer drug resistance. Annu Rev Med 2002; 53: 615-27.

11. Demir S, Aliyazicioglu Y, Turan I, Misir S, Mentese A, Yaman SO, Akbulut K, Kilinc K, Deger O. Antiproliferative and proapoptotic activity of Turkish propolis on human lung cancer cell line. Nutr Cancer 2016; 68: 165-72.
12. Nabende PN, Karanja SM, Mwatha JK, Wachira SW. Anti-proliferative activity of Prunus africana, Warburgia stuhlmannii and Maytenus senegalensis extracts in breast and colon cancer cell lines. Eur J Med Plants 2015; 5: 366-76.

13. Poongodi T, Srikanth R, Lalitha G. Phytochemistry, GC-MS analysis and in vitro cytotoxic activity of Prunus angustifolia leaves against MCF-7 breast cancer cell line. WJPPS 2015; 4: 1489-99.

14. Noratto G, Porter W, Byrne D, Cisneros-Zevallos C. Polyphenolics from peach (Prunus persica var. Rich Lady) inhibit tumor growth and metastasis of MDA-MB-435 breast cancer cells in vivo. J Nutr Biochem 2014; 25: 796-800.

15. Turan I, Demir S, Misir S, Kilinc K, Mentese A, Aliyazicioglu Y, Deger O. Cytotoxic effect of Turkish propolis on liver, colon, breast, cervix and prostate cancer cell lines. Trop J Pharm Res 2015; 14: 777-82.

16. Alasalvar C, Al-Farsi M, Shahidi F. Compositional characteristics and antioxidant components of cherry laurel varieties and pekmez. J Food Sci 2005; 70: 47-52.

17. Karahalil FY, Sahin H. Phenolic composition and antioxidant capacity of Cherry laurel (Laurocerasus officinalis Roem.) sampled from Trabzon region, Turkey. Afr J Biotechnol 2011; 10: $16293-9$

18. Slinkard K, Singleton VL. Total phenol analyses: automation and comparison with manual methods. Am J Enol Vitic 1977; 28: 49-55.

19. Mosmann T. Rapid colorimetric assay for cellular growth and survival: application to proliferation and cytotoxicity assays. J Immunol Methods 1983; 65: 55-63.

20. Dai J, Mumper RJ. Plant phenolics: Extraction, analysis and their antioxidant and anticancer properties. Molecules 2010; 15: 7313-52.

21. Vinson JA, Su X, Zubik L, Bose P. Phenol antioxidant quality in food: fruits. J Agr and Food Chem 2001; 49: 5315-21.

22. Orhan IE, Akkol EK. Estimation of neuroprotective effects of Laurocerasus officinalis Roem. (cherry laurel) by in vitro methods. Food Res Int 2011; 44: 818-22. 
23. Lee BB, Cha MR, Kim SY, Park E, Park HR, Lee SC. Antioxidative and anticancer activity of extracts of cherry (Prunus serrulata var. spontanea) blossoms. Plant Foods Hum Nutr 2007; 62: 79-84.

24. Galati G, O’Brien PJ. Potential toxicity of flavonoids and other dietary phenolics: significance for their chemopreventive and anticancer properties. Free Radic Biol Med 2004; 37: 287-303.

25. Fujii T, Ikami T, Xu JW, Ikeda KJ. Prune extract (Prunus domestica L.) suppresses the proliferation and induces the apoptosis of human colon carcinoma Caco-2. Nutr Sci Vitaminol 2006; 52: 389-91.

26. Adachi M, Suzuki Y, Mizuta T, Osawa T, Adachi T, Osaka K, et al. The "Prunus mume Sieb. et Zucc" (Ume) is a rich natural source of novel anti-cancer substance. Int J Food Prop 2007; 10: $375-84$.

27. Jeong JT, Moon JH, Park KH, Shin CS. Isolation and characterization of a new compound from Prunus mume fruit that inhibits cancer cells. J Agric Food Chem 2006; 54: 2123-8.

28. Sunaga N, Hiraishi K, Ishizuka T, Kaira K, Iwasaki Y, Jimma F, et al. MK615, a compound extract from the Japanese apricot "Prunus mume" inhibits in vitro cell growth and interleukin-8 expression in non-small cell lung cancer cells. J Cancer Sci Ther 2011; S11: 002.
29. Rice-Evans CA, Miller NJ, Paganga G. Antioxidant properties of phenolic compounds. Trends Plant Sci 1997; 2: 152-9.

30. Surh YJ. Cancer chemoprevention with dietary phytochemicals. Nat Rev Cancer 2003; 3: 768-80.

31. Han XZ, Shen T, Lou HX. Dietary polyphenols and their biological significance. Int J Mol Sci 2007; 8: 950-88.

32. Li AN, Li S, Zhang YJ, Xu XR, Chen YM, Li HB. Resources and biological activities of natural polyphenols. Nutrients 2014; 6: 6020-47.

33. Kampa M, Alexaki VI, Notas G, Nifli AP, Nistikaki A, Hatzoglou A, et al. Antiproliferative and apoptotic effects of selective phenolic acids on T47D human breast cancer cells: potential mechanisms of action. Breast Cancer Res 2003; 6: 63-74.

34. Feng R, Lu Y, Bowman YL, Qian Y, Castranova V, Ding M. Inhibition of activator protein-1, NF- $\kappa \mathrm{B}$, and MAPKs and induction of phase 2 detoxifying enzyme activity by chlorogenic acid. J Biol Chem 2005; 290: 27888-95.

35. Jaganathan SK, Supriyanto E, Mandal M. Events associated with apoptotic effect of $p$-coumaric acid in HCT-15 colon cancer cells. World J Gastroenterol 2013; 19: 7726-34. 